\title{
Correction to: Attitudes towards plagiarism among faculty members in Egypt: a cross-sectional study
}

\section{Mona Farouk Ali $^{1}$ iit}

Published online: 13 March 2021

(c) Akadémiai Kiadó, Budapest, Hungary 2021

\section{Correction to: Scientometrics}

\section{https://doi.org/10.1007/s11192-021-03872-8}

In the original publication of the article the author name in the below mentioned reference and its citation was incorrectly published. This has been corrected with this Correction.

The original article has been corrected.

\section{Reference}

Ali, M. F. (2019). Attitudes towards plagiarism among faculty members in Egyptian universities: A field study. International Journal of Library and Information Sciences, 6(2), 14-39. https://doi.org/10. 21608/IJLIS.2019.64129.

Note: The paper was previously published in Arabic language in the International journal of library and information science: a publication of Egyptian Library Association (Ali 2019).

The original article can be found online at https://doi.org/10.1007/s11192-021-03872-8.

Mona Farouk Ali

MONA_MOHAMED@arts.helwan.edu.eg

1 Department of Information Science, Faculty of Arts, Helwan University, Cairo, Egypt 